\title{
Characteristics of Beet Soilborne Mosaic Virus, a Furo-like Virus Infecting Sugar Beet
}

G. B. Heidel and C. M. Rush, Texas Agricultural Experiment Station, P.O. Drawer 10, Bushland, TX 79012; T. L. Kendall, Pioneer Hi-Bred International, 7300 Northwest 62nd Avenue, P.O. Box 38, Johnston, IA 50131-0038; S. A. Lommel, Department of Plant Pathology, Box 7616, North Carolina State University, Raleigh, NC 27695-7616; and R. C. French, University of Nebraska, USDA ARS-Plant Pathology Department, 406 Plant Science, Lincoln, NE 68583

\begin{abstract}
Heidel, G. B., Rush, C. M., Kendall, T. L., Lommel, S. A., and French, R. C. 1997. Characteristics of beet soilborne mosaic virus, a furo-like virus infecting sugar beet. Plant Dis. 81:10701076.

Beet soilborne mosaic virus (BSBMV) is a rigid rod-shaped virus transmitted by Polymyxa betae. Particles were $19 \mathrm{~nm}$ wide and ranged from 50 to over $400 \mathrm{~nm}$, but no consistent modal lengths could be determined. Nucleic acids extracted from virions were polyadenylated and typically separated into three or four discrete bands of variable size by agarose-formaldehyde gel electrophoresis. RNA 1 and 2, the largest of the RNAs, consistently averaged 6.7 and $4.6 \mathrm{~kb}$, respectively. The sizes and number of smaller RNA species were variable. The molecular mass of the capsid protein of BSBMV was estimated to be $22.5 \mathrm{kDa}$. In Northern blots, probes specific to the 3' end of individual beet necrotic yellow vein virus (BNYVV) RNAs 1-4 hybridized strongly with the corresponding BNYVV RNA species and weakly with BSBMV RNAs 1, 2, and 4. Probes specific to the 5' end of BNYVV RNAs 1-4 hybridized with BNYVV but not with BSBMV. No cross-reaction between BNYVV and BSBMV was detected in Western blots. In greenhouse studies, root weights of BSBMV-infected plants were significantly lower than mock-inoculated controls but greater than root weights from plants infected with BNYVV. Results of serological, hybridization, and virulence experiments indicate that BSBMV is distinct from BNYVV. However, host range, capsid size, and the number, size, and polyadenylation of its RNAs indicate that BSBMV more closely resembles BNYVV than it does other members of the genus Furovirus.
\end{abstract}

In Texas in 1988, a virus in sugar beet was identified as being morphologically similar to beet necrotic yellow vein virus (BNYVV) but serologically distinct (25). This virus was designated Texas 7 (TX7). Wisler et al. $(43,44)$ examined relationships between BNYVV and eight other rod-shaped virus isolates from Texas, Nebraska, and Idaho that were serologically indistinguishable from TX7. They coined the name beet soilborne mosaic virus (BSBMV) to identify these isolates and others with similar serological reaction.

Foliar symptoms in beets caused by BSBMV include slight leaf distortion,

Corresponding author: C. M. Rush

Telephone: (806) 354-5804

Fax: (806) 354-5829

E-mail: cm-rush@tamu.edu

Partial funding for this research was supplied by USDA-NRI Grant \#94-37312-0739, the Texas Higher Education Coordinating Board Project Number 999902-146, the Holly Growers' Research Committee, and the Beet Sugar Development Foundation.

Accepted for publication 12 June 1997.

Publication no. D-1997-0717-01R

(C) 1997 The American Phytopathological Society subtle overall mottling, and light yellow vein banding, which, as leaves age, can progress to broad chlorotic areas that usually remain associated with the veins. Some BSBMV isolates cause bright yellow veinal chlorosis more typically associated with infection by BNYVV (33). Systemic foliar symptoms caused by BSBMV appear in field-grown sugar beets more frequently than do those caused by BNYVV, which occur only rarely. Although roots of sugar beets exhibiting foliar symptoms of BSBMV are often asymptomatic, some beets systemically infected with BSBMV exhibit root symptoms more typically associated with rhizomania, the disease caused by BNYVV in sugar beets. Symptoms of rhizomania can include stunting, proliferation of lateral roots, and constriction of the main taproot $(9,30,39)$. Several such beets have been positive in ELISA for BSBMV but negative for BNYVV (33). The effects of BSBMV on sugar beet quality and yield have not yet been determined.

BNYVV and beet soilborne virus (BSBV) are multipartite, rigid, rod-shaped viruses that infect sugar beet and are transmitted, like BSBMV (44), by $\mathrm{Po}$ lymyxa betae Keskin. BNYVV and BSBV are tentative members of the genus Furovi- rus $(13,30,39)$. Yield loss due to BSBV has been reported in mechanically inoculated sugar beet in greenhouse studies, but in field-grown sugar beets BSBV-infected plants are usually asymptomatic (15). Conversely, BNYVV reduces both sugar content and root yield. BNYVV is composed of particles 390, 265, 100, and 85 $\mathrm{nm}$ long and $20 \mathrm{~nm}$ wide (27). Although most isolates of BNYVV are quadripartite, some isolates from Japan have a fifth RNA (30). RNA species are $6.8,4.7,1.8,1.5$, and $1.45 \mathrm{~kb}$ in size and are polyadenylated at the $3^{\prime}$ end $(3,28,30)$. BSBV particle lengths are 300,150 , and $65 \mathrm{~nm}(13)$. The viral RNAs are not polyadenylated and are 3.6 and $3.2 \mathrm{~kb}$, with a possible $6.0-\mathrm{kb}$ species (16). The fact that BNYVV possesses four or five polyadenylated RNA species separates it from other members of the genus Furovirus, which, like the type member soilborne wheat mosaic virus, are typically bipartite or tripartite and lack the 3 '-polyA tail $(3,30)$.

BNYVV and BSBMV are widely distributed throughout the sugar beet-growing region of Texas (11), and isolates of BSBMV have been identified in California, Colorado, Idaho, Nebraska, Wyoming (33), and, most recently, Minnesota (45). BSBMV has not been identified outside of the United States. Often, BSBMV and BNYVV are found in the same field and even in the same plant. Because of the morphological similarities between BSBMV and BNYVV and the possibility that BSBMV can cause symptoms similar to those associated with rhizomania, some similarities and differences between these two viruses were characterized. Here we report some biological, physical, and serological characteristics of BSBMV and the severity of the disease it induces under greenhouse conditions. Accounts of a portion of this study have been published $(12,31,32)$.

\section{MATERIALS AND METHODS}

Virus source and purification. Sugar beets exhibiting typical foliar symptoms of BSBMV were collected from three locations in the Texas sugar beet-growing region and maintained in pots in the greenhouse (11). Symptomatic leaf tissue was tested for BSBMV and BNYVV by DASELISA as previously described (11) with 
some modifications. IgG to BSBMV and biotinylated $\operatorname{IgG}$ (11) were used at 5.0 or $3.0 \mu \mathrm{g} / \mathrm{ml}$. Antibody incubation steps were $3-5 \mathrm{~h}$ at $37^{\circ} \mathrm{C}$ with an overnight sample incubation at $4^{\circ} \mathrm{C}$ and a blocking step of 1$2 \mathrm{~h}$ at $37^{\circ} \mathrm{C}$. Substrate was added at 1.0 $\mathrm{mg} / \mathrm{ml}$. IgG to BNYVV was obtained from a commercial source (American Plant Diagnostics Inc., South Bend, IN) and was diluted 1:1,000 (v/v).

For virus increase, symptomatic sugar beet leaf tissue was ground in $0.1 \mathrm{M}$ potassium phosphate buffer (KPB), $\mathrm{pH} 7.4$, with $0.02 \mathrm{M}$ sodium sulfite (inoculation buffer), and the extract was rubbed onto leaves of Chenopodium quinoa Willd. (a local lesion host of BSBMV) (44) previously dusted with 600-mesh Carborundum. For RNA analysis, the virus was passaged no more than four times through $C$. quinoa before being purified. BSBMV was purified as described by Kendall et al. (17) and Shirako and Brakke (36) with several modifications. The grinding buffer was amended with 2-mercaptoethanol to a final concentration of $0.1 \%(\mathrm{v} / \mathrm{v})$. After the first low-speed centrifugation, the supernatant was strained through Miracloth (Calbiochem, La Jolla, CA). The first high-speed pellet was resuspended overnight at $4^{\circ} \mathrm{C}$ in $0.05 \mathrm{M}$ borate buffer, $\mathrm{pH} 8.0$, with $1 \mathrm{mM}$ EDTA (resuspension buffer), and the second high-speed pellet was resuspended and either used immediately for nucleic acid extraction or stored at $-20^{\circ} \mathrm{C}$. BNYVV from infected $C$. quinoa and healthy $C$. quinoa extracts used as controls were prepared in the same manner.

Nucleic acid analysis. BSBMV RNAs were extracted from virions in purified preparations with chloroform and phenol (1:1) in $2 \times$ STE (34) with $1 \%$ sodium dodecyl sulfate (SDS), precipitated in three volumes of ethanol at $-20^{\circ} \mathrm{C}$ and electrophoresed through a $1 \%$ agarose-formaldehyde denaturing gel in the presence of 0.5 $\mu \mathrm{g} / \mathrm{ml}$ ethidium bromide $(10,17,34)$. $\mathrm{Nu}-$ cleic acid sizes were estimated relative to a 0.24-9.5 kb RNA ladder (Gibco BRL, Gaithersburg, MD). BNYVV or maize chlorotic mottle virus (MCMV, $4.4 \mathrm{~kb}$ ) (26) were included as controls. MCMV RNA was provided by S. A. Lommel, North Carolina State University.

Polyadenylation of BSBMV RNA was determined by passage through an oligo (dT) cellulose column (Gibco BRL) according to the manufacturer's instructions. Red clover necrotic mosaic virus and potato virus Y RNAs were provided (S. A. Lommel) and used as non-polyadenylated and polyadenylated controls, respectively $(8,46)$. Polyadenylated RNA was visualized by staining with ethidium bromide in $1 \%$ agarose gels.

For Northern hybridization, radioactive probes were generated by reamplification of BNYVV polymerase chain reaction (PCR) products $(31,35,44)$. BNYVV probes were made using primers specific for sequences from the $3^{\prime}$ and $5^{\prime}$ region of each RNA species of BNYVV (44). A 20$\mu \mathrm{l}$ PCR mix included $5 \mu \mathrm{l}$ of the PCR product, $\quad 50 \mu \mathrm{Ci} \quad\left[\alpha-{ }^{32} \mathrm{P}\right] \mathrm{dCTP} \quad(3,000$ $\mathrm{Ci} / \mathrm{mmole}$ ), $0.2 \mathrm{mM}$ each dNTP, 20 pmole primers (32), 1 unit of Taq DNA polymerase (Cetus), and PCR buffer supplied by the manufacturer. PCR parameters were as previously described (32) except that the first 10-min extension step was omitted, and the number of cycles was reduced to 30. Following cDNA amplification, the layer of oil was removed by emulsification with chloroform and centrifugation, and the probes were isolated by placing the aqueous phase in a Millipore filter $(10,000$ NMWL filter unit), adding $100 \mu \mathrm{l}$ of distilled water, and centrifuging at $6,000 \mathrm{rpm}$ until $10-50 \mu$ remained in the filter. This was performed two additional times to remove small fragments and unincorporated $\left[\alpha_{-}{ }^{32} \mathrm{P}\right] \mathrm{dCTP}$. The remaining concentrated probe solution was diluted with 100 $\mu \mathrm{l}$ of distilled water. In addition, RNA isolated from purified virion preparations and fractionated using the PolyATtract System 1000 (Promega) according to the manufacturer's instructions was used as template for synthesis of radiolabeled viral cDNA probes by incorporation of $[\alpha-$ $\left.{ }^{32} \mathrm{P}\right] \mathrm{dCTP}$ using an oligo dT primer and reverse transcriptase as described (34). The PolyATtract System was originally designed for use in separating mRNA from total RNA extractions, and a similar system has been used in isolating BNYVV RNA from infected root tissue (23). Northern blots were prepared by separating the viral RNAs on $1 \%$ agarose gels and blotting them by capillary transfer to ZetaProbe membranes according to the supplier's instructions (Bio-Rad). The blots were hybridized overnight using $25 \mu \mathrm{l}$ of the probe preparations under high stringency (0.5 M NaH $\mathrm{PO}_{4}, \mathrm{pH} 7.2$, with 1 mM EDTA and $7 \%$ SDS at $65^{\circ} \mathrm{C}$ ) followed by washes in $40 \mathrm{mM} \mathrm{NaH}{ }_{2} \mathrm{PO}_{4}, \mathrm{pH} \mathrm{7.2,} \mathrm{at}$ $65^{\circ} \mathrm{C}(6,34)$.

Capsid and serological analysis and electron microscopy. Purified virions were denatured, and the capsid protein was separated in a discontinuous $12 \%$ sodium dodecyl sulfate-polyacrylamide gel (SDSPAGE; $8 \times 7 \mathrm{~cm}$, Hoefer, San Francisco, CA) and stained with Coomassie Brilliant Blue R-250 (24). Capsid molecular mass was estimated using a 14.3-200 kilodalton $(\mathrm{kDa})$ molecular mass standard (Gibco BRL). For Western blot analysis, BSBMV and BNYVV coat proteins were subjected to SDS-PAGE and electroblotted to nitrocellulose membranes in Towbin's buffer (42). An extract from noninfected $C$. quinoa, prepared by the virion purification procedure described above, was included in the transfer, as well as a prestained molecular weight standard (Amersham International plc, Buckinghamshire, England). Membranes were probed with $\mathrm{IgG}$ to BSBMV diluted to approximately $1 \mu \mathrm{g} / \mathrm{ml}$ or IgG to BNYVV diluted 1:500, and the bound IgG was detected with goat antirabbit alkaline phosphatase conjugate. Antisera used were the same as those supplied for DAS-ELISAs. Blots were visualized with nitro blue tetrazolium and 5bromo-4-chloro-3-indolyl phosphate $(1,42)$. For SDS-PAGE and Western blot analyses, the concentration of BSBMV and BNYVV virus preparations were adjusted to approximately $1.6 \mathrm{mg} / \mathrm{ml}$, assuming an $\mathrm{E}^{0.1 \%}{ }_{260}$ of $3.0(22)$.

In early attempts to measure particle lengths, leaf dips were prepared directly from infected $C$. quinoa or sugar beet leaf tissue extracts. However, this method was inadequate for obtaining a number of particles high enough for measurement. Therefore, three methods were used in attempt to concentrate BSBMV particles to determine lengths and width while maintaining particle integrity.

In the first experiment, particles were concentrated from naturally infected sugar beet leaf tissue by carrying the virion purification procedure described above, with slight modification, through the first ultracentrifugation step. Leaf tissue was ground in ice cold borate buffer $(7.5: 1, \mathrm{v} / \mathrm{w})$ using a mortar and pestle. After the first ultracentrifugation step, the pellet was resuspended, and particles were stained with $2 \%$ phosphotungstic acid (PTA), pH 6.2.

In the second experiment, virions were analyzed by serologically specific electron microscopy (SSEM) (7). Grids were incubated for $1 \mathrm{~h}$ at $24^{\circ} \mathrm{C}$ on IgG to BSBMV diluted $1: 100$ in $0.05 \mathrm{M}$ Tris buffer, $\mathrm{pH}$ 7.2. Antiserum used for SSEM was the same as that provided for DAS-ELISA. Symptomatic beet leaf tissue was ground in $0.05 \mathrm{M}$ Tris buffer, $\mathrm{pH}$ 8.4, with $0.4 \mathrm{M}$ sucrose and $0.15 \mathrm{M} \mathrm{NaCl}$ (TSS) using a mortar and pestle. The extract was briefly clarified by centrifugation at $11,000 \times g$ for approximately $2 \mathrm{~min}$. After washing with Tris buffer, grids were incubated on a drop of plant extract for $4 \mathrm{~h}$ at $24^{\circ} \mathrm{C}$, washed first with TSS and then with a steady stream of distilled water. Particles were stained with PTA.

In the third experiment, grids were incubated for $45 \mathrm{~min}$ on IgG to BSBMV diluted 1:100 in $0.1 \mathrm{M}$ sodium phosphate buffer, $\mathrm{pH}$ 7.0, and washed with sterile distilled water. $C$. quinoa leaf tissue infected with BSBMV was ground in $0.1 \mathrm{M}$ sodium phosphate buffer, $\mathrm{pH} 7.0$, and the extract was clarified by brief centrifugation. IgG-coated grids were incubated on the extract for $45 \mathrm{~min}$ and washed with sterile distilled water, and particles were stained with $2 \%$ uranyl acetate. Particles in all three experiments were viewed using a Zeiss EM 109 electron microscope.

Host range. Purified BSBMV was inoculated to $C$. quinoa, and the virus was maintained by mechanical transmission. Inoculum was prepared from symptomatic leaf tissue ground in inoculation buffer, 


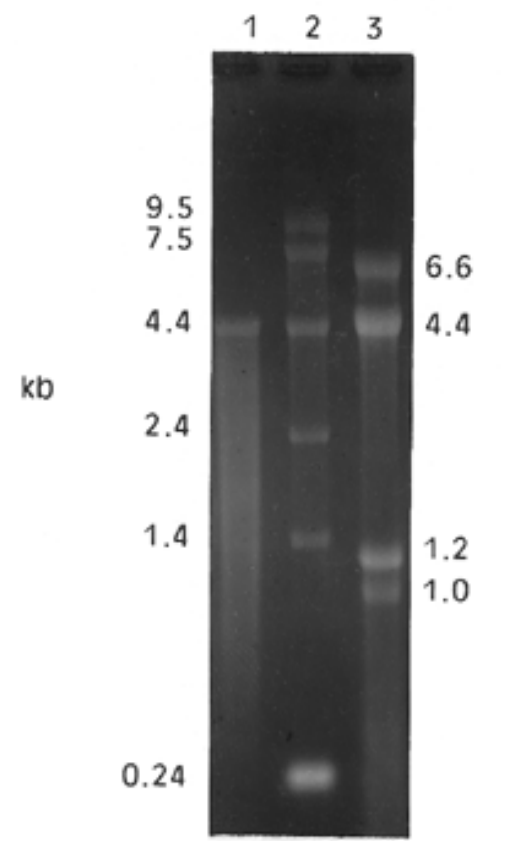

Fig. 1. RNA analysis of beet soilborne mosaic virus in a $1 \%$ agarose formaldehyde denaturing gel. RNA standards (lane 2; Gibco BRL) and BSBMV extracted from a virion preparation (lane 3) and their RNA sizes in kilobases (kb) are indicated on left- and right-hand sides of the panel, respectively. Maize chlorotic mottle virus genomic RNA is in lane 1 (4.4 kb) (26).

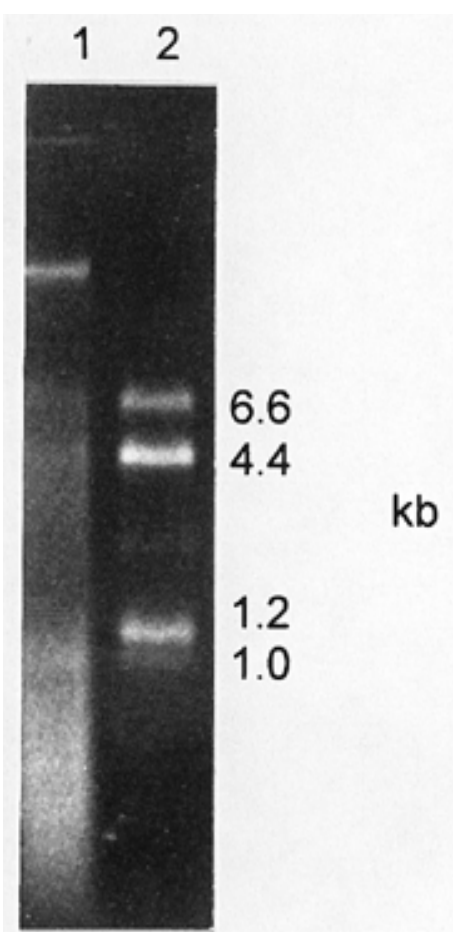

Fig. 2. Nondenaturing agarose gel electrophoresis of bound (lane 2) and nonbound (lane 1) fractions of beet soilborne mosaic virus RNA extracted from purified virions after passage through an oligo (dT) cellulose column. The origin of the high molecular weight band in the nonbound fraction is not known. Sizes in kilobases $(\mathrm{kb})$ of RNA contained in the bound fraction are indicated on the right. and the extract was rubbed on leaf tissue of plants to be tested. Host range test plants mock-inoculated with buffer were used as controls, and tests were conducted in the greenhouse. Plants were observed periodically for at least 4 weeks, and symptomatic and asymptomatic leaf tissue were backinoculated to $C$. quinoa. Some BSBMV host plants have been reported previously (44). Here, the following 27 plant species representing 12 families were assayed: Tetragonia tetragonioides (Pall.) Kuntze (Aizoaceae); Amaranthus hybridus L. (Amaranthaceae); Cichorium endivia L., Helianthus annuus L. and Lactuca sativa L. (Asteraceae); Brassica oleracea L. var. botrytis L., B. oleracea L. var. capitata L., $B$. oleracea L. var. gongylodes L., B. rapa L. and Raphanus sativus L. (Brassicaceae); Beta maritima L., Chenopodium album L., (Chenopodiaceae); Citrullus lanatus (Thunb.) Matsum. \& Nakai and Cucurbita pepo L. (Cucurbitaceae); Arachis hypogaea L., Glycine max (L.) Merr., Phaseolus vulgaris L. and Vigna unguiculata (L.) Walp. (Fabaceae); Gossypium hirsutum L. (Malvaceae); Sorghum bicolor (L.) Moench, Triticum aestivum L. and Zea mays L. (Poaceae); Capsicum annuum L., Lycopersicon esculentum Miller, Nicotiana tabacum L. (Samsun and Hicks) and Solanum melongena L. (Solanaceae); and Tropaeolum majus L. (Tropaeolaceae).

Virulence evaluation. Seed of sugar beet cultivar HH67 (Holly Hybrids, Sheridan, WY) were planted in sand in $9-\mathrm{cm}^{2}$ pots in the greenhouse. Seedlings were rinsed free of sand, and 25 8- to 12-day-old plants were placed in 50-ml plastic centrifuge tubes and vortexed for $45 \mathrm{~s}$ in $5 \mathrm{ml}$ of inoculum containing $0.12 \mathrm{~g}$ of 600 -mesh Carborundum. This procedure is similar to that previously described (14). Inoculum consisted of $2 \mathrm{~g}$ of symptomatic $C$. quinoa leaf tissue infected with BNYVV or BSBMV that was ground, using a mortar and pestle, in $5 \mathrm{ml}$ of inoculation buffer. The original inoculum used for virus increase was obtained from naturally systemically infected sugar beet leaf tissue, and the virus was passaged twice in $C$. quinoa. Seedlings were left in the inoculum for $5 \mathrm{~min}$ after vortexing and then rinsed with deionized water. Four seedlings were planted in a sand/commercial topsoil mixture in 2.5 - $\mathrm{L}$ containers. Healthy controls consisted of seedlings vortexed in 5 $\mathrm{ml}$ of inoculation buffer containing $0.12 \mathrm{~g}$ of Carborundum and of seedlings transplanted without being vortexed. Ten replications were arranged in randomized complete blocks on one greenhouse bench. Nine weeks after planting, symptomatic leaf tissue from plants that survived transplanting was tested for BSBMV and BNYVV by DAS-ELISA, except these tests used IgG purified from polyclonal antisera raised in rabbits to BSBMV or BNYVV denatured capsid. IgG to BSBMV and IgG-biotin and IgG to BNYVV and IgG-biotin were used at 1.0 and $4.0 \mu \mathrm{g} / \mathrm{ml}$, respectively. Asymptomatic leaf tissue was tested if no symptoms were evident. Plants were thinned 15 weeks after planting to the largest and most vigorous plant that tested positive (or negative, in the case of the healthy controls) for the respective virus. If no beets tested positive in a virus treatment replication, the largest plant was left to grow in the container. Plants were harvested 24 weeks after planting, and top and root dry weights were determined after drying at $58-60^{\circ} \mathrm{C}$. The experiment was repeated once. Data were analyzed by the GLM program (SAS Institute), and treatment means were separated by Duncan's multiple range test $(P=0.05)$.

\section{RESULTS}

Nucleic acid analysis. Nucleic acids extracted from purified BSBMV preparations from three isolates separated into three or four discrete bands with estimated sizes of 6.6, 4.4, 1.2, and $1.0 \mathrm{~kb}$ (Fig. 1); 6.7, 4.9, and $1.8 \mathrm{~kb}$; and 6.7, 4.6, 1.8, and $1.4 \mathrm{~kb}$ (results not shown), respectively, as determined by formaldehyde denaturing gel electrophoresis in three experiments. Proposed RNA numerical designations for BSBMV, in order of descending size, are shown in Table 1. BSBMV RNA sizes are compared to those reported for BNYVV (30). Banding patterns of BSBMV RNA bound by oligo (dT) cellulose (Fig. 2) were similar to those produced by BSBMV RNA in the denaturing gel, indicating the presence of a poly-A sequence in the genome.

Table 1. Proposed BSBMV RNA numerical designations compared to those of BNYVV (30) based on separation of RNAs in $1 \%$ agarose formaldehyde denaturing gels in three experiments ${ }^{\mathrm{w}}$

\begin{tabular}{llcccc}
\hline & \multicolumn{5}{c}{ RNA number } \\
\cline { 2 - 6 } Virus & $\mathbf{1}$ & $\mathbf{2}$ & $\mathbf{3}$ & $\mathbf{4}$ & $\mathbf{5}$ \\
\hline BSBMV & $6.6^{\mathrm{x}}$ & 4.4 & $-^{\mathrm{y}}$ & $1.2^{\mathrm{z}}$ & $1.0^{\mathrm{z}}$ \\
& 6.7 & 4.9 & 1.8 & $--^{\mathrm{y}}$ & $-_{\mathrm{y}}^{\mathrm{y}}$ \\
BNYVV & 6.7 & 4.6 & 1.8 & 1.4 & $-^{\mathrm{y}}$ \\
\hline
\end{tabular}

${ }^{\mathrm{w}}$ RNA was extracted from virions in purified preparations of three BSBMV isolates collected in Texas.

${ }^{\mathrm{x}}$ RNA size in $\mathrm{kb}$.

${ }^{y}$ No band observed.

${ }^{z}$ These may represent shortened versions of RNAs 3 and 4 similar to those reported for BNYVV $(2,5,20,29)$ 
Radioactive probes generated from RTPCR products near the $3^{\prime}$ end of each BNYVV RNA hybridized strongly with the corresponding BNYVV RNA and weakly with corresponding BSBMV RNAs 1, 2, and 4 but not with BSBMV RNA 3. Probes specific for the $5^{\prime}$ end of each BNYVV RNA hybridized only with the corresponding BNYVV RNA. A representative reaction using probes made to BNYVV RNA 2 is shown in Figure 3. Probes made from unfractionated cDNA of BNYVV or BSBMV reacted strongly with all four RNA species in each homologous reaction but also reacted weakly in heterologous reactions (data not shown).

Capsid and serological analysis and electron microscopy. The molecular mass of BSBMV capsid protein was estimated by SDS-PAGE to be $22.5 \mathrm{kDa}$ (Fig. 4). BSBMV capsid protein consistently migrated slightly slower than that of BNYVV. In Western blots, BSBMV and BNYVV proteins reacted only with the homologous antiserum, and no reaction with healthy $C$. quinoa extracts was detected (Fig. 5).

Particle width of BSBMV was estimated to be $19 \mathrm{~nm}$ (Fig. 6). Particle lengths in each of the three experiments were grouped into 10-nm-wide classes for frequency analysis. Results from each of the experiments were generally unsatisfactory, with particle lengths not consistently falling into size classes expected based on the RNA lengths of BSBMV. Particle lengths determined in the first experiment, in

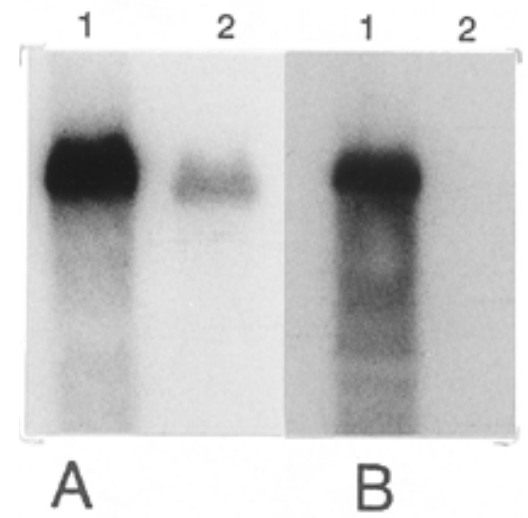

Fig. 3. Representative Northern blot analyses of beet necrotic yellow vein virus (BNYVV; lane 1) and beet soilborne mosaic virus (BSBMV; lane 2) using $\left[\alpha^{-32} \mathrm{P}\right] \mathrm{dCTP}$-labeled probes reamplified from BNYVV PCR products generated using primers specific to the $3^{\prime}$ (A) and $5^{\prime}$ (B) ends of BNYVV RNA 2. The sizes of the 3' and $5^{\prime}$ probes were 312 and 209 bases, respectively. The probe specific to the 3' end of BNYVV RNA 2 had a reverse primer (5' TTCACACCCAGTCAGTA 3') that annealed to nucleotide 4574 , and the upstream primer $\left(5^{\prime}\right.$ AACTTAAATGCAAGAAAC 3') annealed to nucleotide 4263 of RNA 2. The reverse primer for the probe specific to the $5^{\prime}$ end of BNYVV RNA 2 (5' CGTACATTAGCAGATGC 3') annealed to nucleotide 484 , and the upstream primer (5' CTGCGAATCTATCTATAA 3') annealed to nucleotide 275 . which virions from a partially purified preparation were measured, were widely distributed with particle modal lengths of $90,100,190$, and $250 \mathrm{~nm}$. In the first and second SSEM experiments, most of the particle lengths fell below 80 or between 90 and $110 \mathrm{~nm}$, respectively. Weaker modal peaks were observed at 240,290, and $390-400 \mathrm{~nm}$ in the second SSEM test.

Host range. BSBMV host plants and their symptoms, as determined by mechanical inoculation, included the following: B. maritima developed necrotic local lesions with yellow halos, followed by development of systemic mottling and stunting of new growth; in C. album, pale yellow local lesions developed on inoculated leaves; T. tetragonioides first developed pale yellow local lesions that later became bright yellow, and this was often followed by necrosis of the entire inoculated leaf. Plants of the remaining species tested did not develop symptoms, and BSBMV was not detected visually (by observation of symptom development) or by DAS-ELISA in $C$. quinoa backinoculated with extracts from asymptomatic leaf tissue.

Virulence evaluation. In the first greenhouse test, 20/33 plants in the BNYVV treatment $(61 \%)$ and $14 / 38$ of plants in the BSBMV treatment $(37 \%)$ were positive when tested by DAS-ELISA for BNYVV and BSBMV, respectively, before plants were thinned. One BNYVV and two BSBMV replications did not include plants testing positive for the respective virus. In the second greenhouse test,

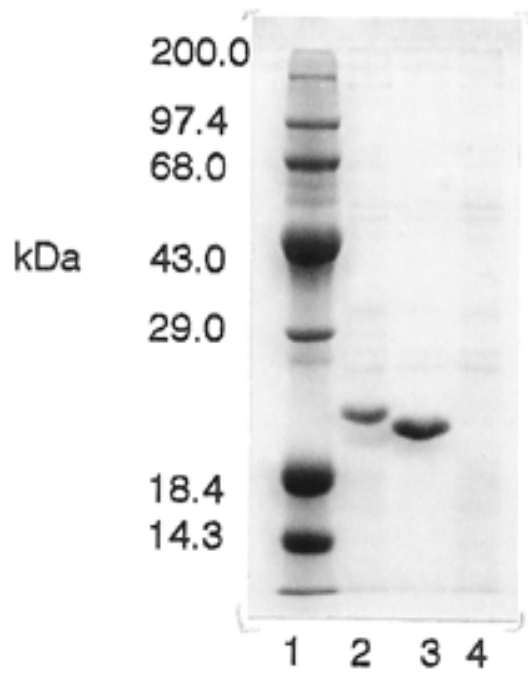

Fig. 4. Analysis of beet soilborne mosaic virus (BSBMV) coat protein (lane 2) in a $12 \%$ sodium dodecyl sulfate-polyacrylamide gel stained with Coomassie Brilliant Blue R-250. Capsid molecular mass was estimated to be 22.5 kilodaltons $(\mathrm{kDa})$. Beet necrotic yellow vein virus capsid (lane 3) has an estimated molecular mass of $21 \mathrm{kDa}$ (27). An extract from uninfected Chenopodium quinoa (lane 4) was included as a control. Molecular masses $(\mathrm{kDa})$ of the protein standards (Gibco BRL; lane 1) are indicated on the left.
$12 / 24$ plants in the BNYVV treatment $(50 \%)$ and $17 / 32$ plants in the BSBMV treatment $(53 \%)$ were positive for BNYVV and BSBMV, respectively, and one BNYVV replication contained no plants that tested positive for BNYVV. None of the plants tested was positive for the heterologous virus, and neither virus was detected in healthy control plants. In the first test, there were no differences among treatments in top dry weights, and in the second greenhouse test the only significant difference in top dry weights was between the mock-inoculated control and BNYVV treatments (Table 2). In both greenhouse tests, root dry weights in the BSBMV and BNYVV treatments were significantly lower than those of both healthy control treatments, and root dry weights in the BNYVV treatment were significantly lower than those in the BSBMV treatment. There was no difference in root weight between the two healthy control treatments.

\section{DISCUSSION}

BNYVV differs fundamentally from other furoviruses in that it possesses $3^{\prime}$ polyadenylated RNA and is composed of more than two particles. Prior to the first report of BSBMV in 1988 (25), the only other multiparticulate rod-shaped virus transmitted by $P$. betae other than BNYVV

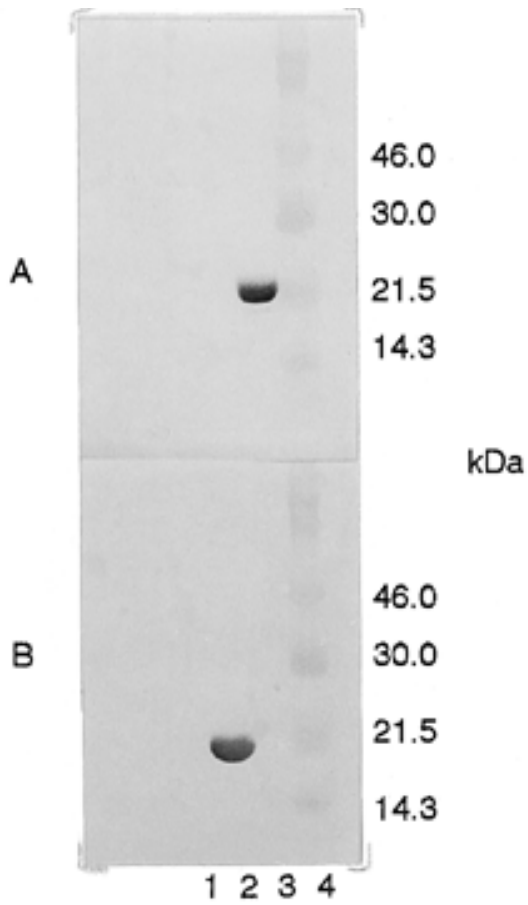

Fig. 5. Western blot analyses of the capsid proteins of beet soilborne mosaic virus (BSBMV; lane 3) and beet necrotic yellow vein virus (BNYVV; lane 2) probed with immunoglobulin $G$ from antisera prepared to (A) BSBMV and (B) BNYVV. An extract from uninfected Chenopodium quinoa (lane 1) was included as a control. Apparent molecular masses of the prestained protein standards (Amersham; lane 4) in kilodaltons (kDa) are indicated on the right. 
known to infect sugar beet was BSBV. Because of the size of the RNAs and lack of a poly(A) tail, BSBV is considered more similar to other members of the genus Furovirus than to BNYVV (16).

BSBMV, like BNYVV, is transmitted by $P$. betae (44) and is a multiparticulate, rodshaped virus. The RNA is polyadenylated, and the number and size of BSBMV RNAs correspond closely to those of BNYVV. BSBMV RNAs 1 and 2 have been observed in all samples studied and correspond roughly in size to those reported for BNYVV RNAs 1 and 2 (30). Although the two larger RNA species of BSBMV appear to be stable with regard to size, variation in length and number of the smaller RNAs is common. This is another characteristic in which BSBMV resembles BNYVV. The absence of one or both of the smaller RNAs of BNYVV has been observed fre-

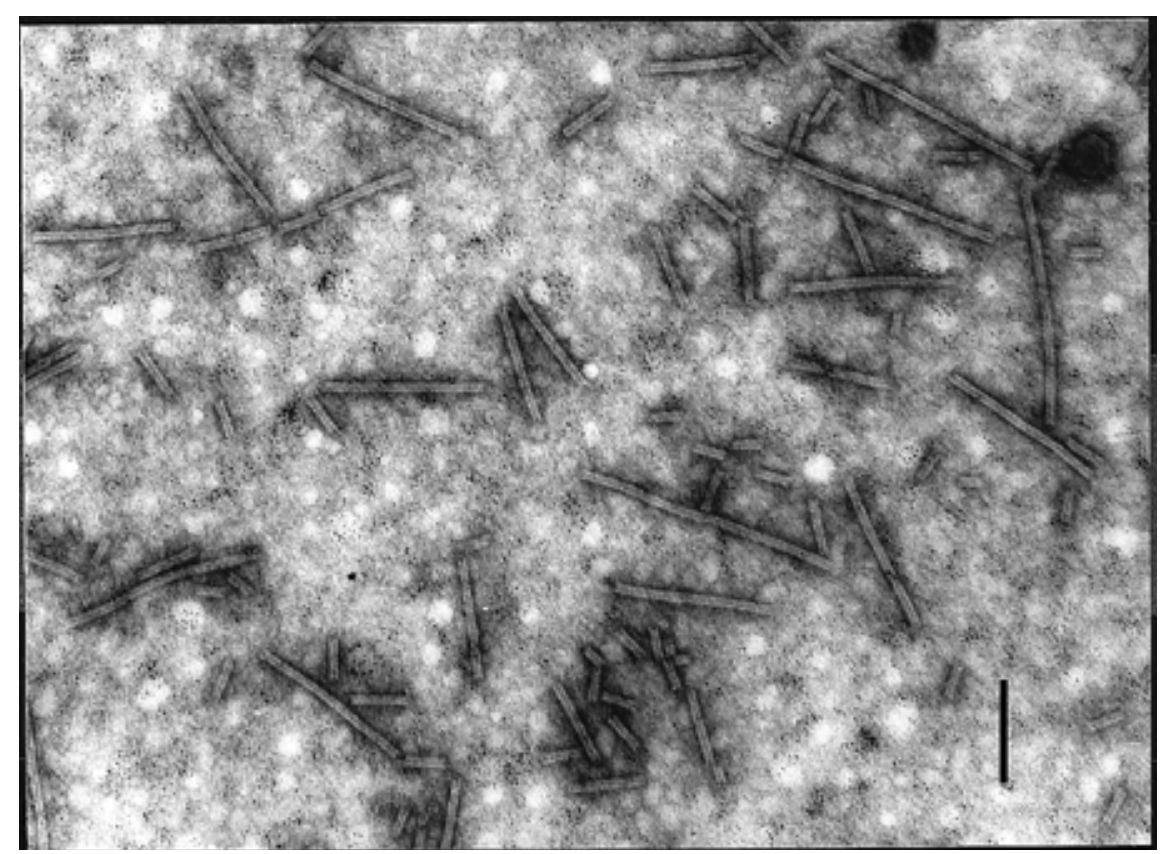

Fig. 6. Particles of beet soilborne mosaic virus in clarified Chenopodium quinoa leaf tissue extract assayed by serologically specific electron microscopy and stained with $2 \%$ phosphotungstic acid. Bar represents $140 \mathrm{~nm}$.

Table 2. Effect of beet soilborne mosaic virus (BSBMV) and beet necrotic yellow vein virus (BNYVV) on top and root dry weights in sugar beet under greenhouse conditions ${ }^{\mathrm{w}}$

\begin{tabular}{llllll}
\hline \multirow{2}{*}{ Treatment } & \multicolumn{2}{c}{ Top weight $(\mathbf{g})^{\mathbf{x}}$} & & \multicolumn{2}{c}{ Root weight $(\mathbf{g})$} \\
\cline { 2 - 3 } \cline { 5 - 6 } \cline { 5 - 6 } & Test $\mathbf{1}$ & Test $\mathbf{2}$ & & Test $\mathbf{1}$ & Test $\mathbf{2}$ \\
\hline Mock-inoculated control & $27.40 \mathrm{a}^{\mathrm{y}, \mathrm{z}}$ & $31.42 \mathrm{a}$ & & $39.14 \mathrm{a}$ & $42.42 \mathrm{a}$ \\
Transplanted control & $24.30 \mathrm{a}$ & $28.69 \mathrm{ab}$ & & $37.35 \mathrm{a}$ & $39.45 \mathrm{a}$ \\
BSBMV & $24.90 \mathrm{a}$ & $28.69 \mathrm{ab}$ & & $26.83 \mathrm{~b}$ & $23.59 \mathrm{~b}$ \\
BNYVV & $27.40 \mathrm{a}$ & $24.51 \mathrm{~b}$ & & $15.73 \mathrm{c}$ & $10.18 \mathrm{c}$ \\
\hline
\end{tabular}

${ }^{\mathrm{w}}$ Sugar beet seedlings were mechanically inoculated by vortexing with Carborundum in inoculum consisting of BSBMV- or BNYVV-infected C. quinoa leaf tissue ground in inoculation buffer. Healthy controls consisted of seedlings mock-inoculated with inoculation buffer + Carborundum and of seedlings transplanted without being vortexed.

${ }^{x}$ Dry weights were determined after plant tops and roots were dried at $58-60^{\circ} \mathrm{C}$ until no change in weight was detected.

${ }^{y}$ Means are the average of 10 single-plant replications. The presence or absence of virus was confirmed by DAS-ELISA.

${ }^{z}$ Means followed by the same letter within columns are not significantly different according to Duncan's multiple range test $(P=0.05)$. variation in the number and size of BSBMV RNA species.

Depending on the antiserum used, serological cross reactivity between BSBMV and BNYVV in Western blots has been reported $(43,44)$. Cross reactions also have been observed in ELISA (J. S. Gerik, personal communication) (44). Under the conditions of our tests, no cross reactivity was detected in Western blots or ELISAs. Conflicting reports from different laboratories concerning cross reactivity between BSBMV and BNYVV are problematic. Varying results could be due to different techniques or antisera (18). However, due to the importance of correct diagnosis, researchers working with BNYVV and BSBMV need to determine the source of variation and develop accurate, sensitive, and dependable techniques to differentiate these two viruses.

Because BSBMV particle morphology and the length and number of its RNAs are similar to those of BNYVV, the particle size distribution was expected to also be similar. Previous attempts to prepare leaf dips directly from $C$. quinoa or sugar beet leaf tissue extracts failed to produce an adequate number of particles for measurement (data not shown). To avoid potential particle fracturing or aggregation caused by purification $(3,4)$ or by the use of PTA, particles were examined by SSEM from clarified sap and stained with uranyl acetate. Still, no clear histogram peaks emerged in length ranges expected for BSBMV. Fracturing may have been due to the $\mathrm{pH}$ or salt concentration of buffers used in the SSEM studies, resulting in a high number of shorter particles and relatively few longer particles.

Based on results of the greenhouse study, BSBMV is mildly virulent. Sugar beets infected with BSBMV had significantly reduced root weight compared to those of the healthy controls, but root weight of beets in the BSBMV treatment was significantly greater than that of beets in the BNYVV treatment. Results from the greenhouse study indicated that, under certain conditions, BSBMV has the potential to cause damage in sugar beets, though to a lesser degree than BNYVV. A field study, in which sugar beets are grown in a more natural environment, is needed to confirm the results of the greenhouse study.

BSBMV is serologically distinct from BNYVV and causes foliar and root symptoms that differ from those caused by BNYVV in naturally infected sugar beets. However, based on particle number and morphology, host range $(38,44)$ transmission by $P$. betae (44), and the presence of polyadenylated RNA (30), we suggest that, under current taxonomic guidelines, BSBMV should be considered a member of the genus Furovirus, more similar to BNYVV than to the Furovirus type virus (soilborne wheat mosaic virus) (36). Al- 
though BNYVV and BSBMV share many traits common to other members of this genus, they are distinct when compared to other furoviruses. Members of this genus typically are composed of two to three particles of varying lengths and lack a $3^{\prime}$ poly-A tail $(4,16,17)$. The question of whether BNYVV should be included in the genus Furovirus because of its distinct qualities has been previously discussed (30). The presence of BSBMV strengthens the case for creating a new genus. BSBMV has been proposed to belong to the Benevirus genus (type species BNYVV) (41). However, "bene" translates as "good" in Latin and modern Italian, so the name submitted for approval by the International Committee on Taxonomy of Viruses is Benyvirus (L. Torrance, personal communication).

Similarities between BNYVV and BSBMV include host range $(38,44)$, capsid protein size, and the presence of a quadripartite genome. Hybridization studies using probes specific to sequences located near the $3^{\prime}$ end of BNYVV indicate some sequence homology between BSBMV and BNYVV. However, near the 5' end, probes were specific for BNYVV, and crosshybridization did not occur. These data suggest that BSBMV and BNYVV are distinct but closely related viruses. The genomic variation that results in differences in symptom expression, biology, and serological reaction remains to be determined.

\section{LITERATURE CITED}

1. Blake, M. S., Johnston, K. H., RussellJones, G. J., and Gotschlich, E. C. 1984. A rapid, sensitive method for detection of alkaline phosphatase-conjugated antiantibody on western blots. Anal. Biochem. 136:175-179.

2. Bouzoubaa, H., Guilley, H., Jonard, G., Richards, K., and Putz, C. 1985. Nucleotide sequence analysis of RNA-3 and RNA-4 of beet necrotic yellow vein virus, isolates $\mathrm{F} 2$ and G1. J. Gen. Virol. 66:1553-1564.

3. Brunt, A. A., and Richards, K. E. 1989. Biology and molecular biology of furoviruses. Adv. Virus Res. 36:1-32.

4. Brunt, A. A., and Shikata, E. 1986. Fungustransmitted and similar labile rod-shaped viruses. Pages 305-335 in: The Plant Viruses, Vol. 2. M. H. V. Van Regenmortel and $\mathrm{H}$. Fraenkel-Conrat, eds. Plenum Press, New York.

5. Burgermeister, W., Koenig, R., Weich, H., Sebald, W., and Lesemann, D.-E. 1986. Diversity of the RNAs in thirteen isolates of beet necrotic yellow vein virus in Chenopodium quinoa detected by means of cloned cDNAs. J. Phytopathol. 115:229-242.

6. Church, G. M., and Gilbert, W. 1984. Hybridization protocols for DNA probes. in: Genomic Sequencing. Proc. Natl. Acad. Sci. 81:1991-1995.

7. Derrick, K. S. 1990. Serologically specific electron microscopy. Pages 313-319 in: Serological Methods for Detection and Identification of Viral and Bacterial Plant Pathogens. R. Hampton, E. Ball, and S. DeBoer, eds. APS Press, St. Paul, MN.

8. Dinant, S., Blaise, F., Kusiak, C., AstierManifacier, S., and Albouy, J. 1993. Het- erologous resistance to potato virus $\mathrm{Y}$ in transgenic tobacco plants expressing the coat protein gene of lettuce mosaic potyvirus. Phytopathology 83:818-824.

9. Fujisawa, I., and Sugimoto, T. 1976. Transmission of beet necrotic yellow vein virus by Polymyxa betae. Ann. Phytopathol. Soc. Jpn. 43:583-586.

10. Gerard, G. F., and Miller, K. 1986. Comparison of glyoxal and formaldehyde gels for sizing rRNAs. Gibco BRL Focus 8:5-6.

11. Heidel, G. B., and Rush, C. M. 1994. Distribution of beet necrotic yellow vein virus, beet distortion mosaic virus and an unnamed soilborne sugar beet virus in Texas and New Mexico. Plant Dis. 78:603-606.

12. Heidel, G. B., Rush, C. M., Kendall, T. L., and Lommel, S. A. 1993. Partial characterization of a soilborne sugar beet virus in Texas. (Abstr.) J. Sugar Beet Res. 30:98.

13. Henry, C. M., Jones, R. A. C., and Coutts, R. H. A. 1986. Occurrence of a soil-borne virus of sugar beet in England. Plant Pathol. 35:585-591.

14. Hutchinson, P. J., Henry, C. M., and Coutts, R. H. A. 1993. Mechanical inoculation of sugar beet roots with beet soil-borne virus in the absence of Polymyxa betae. Pages 43-46 in: Proc 2nd Symp. Intl. Work. Group Plant Viruses Fungal Vectors. C. Hiruki, ed. American Society of Sugar Beet Technologists, Denver, CO

15. Kaufmann, A., Koenig, R., and Rohloff, H. 1993. Influence of beet soil-borne virus on mechanically inoculated sugar beet. Plant Pathol. 42:413-417.

16. Kaufmann, A., Li, Y., Koenig, R., Breyel, E., Maiss, E., Lüddecke, P., and Commandeur, U. 1992. Single- and double-stranded RNAs associated with an isolate of beet soil-borne virus. Intervirology 33:97-102.

17. Kendall, T. L., Langenberg, W. G., and Lommel, S. A. 1988. Molecular characterization of sorghum chlorotic spot virus, a proposed furovirus. J. Gen. Virol. 69:2335-2345.

18. Koenig, R. 1978. ELISA in the study of homologous and heterologous reactions of plant viruses. J. Gen. Virol. 40:309-318.

19. Koenig, R., Beier, C., Commandeur, U., Lüth, U., Kaufmann, A., and Lüddecke, P. 1996. Beet soil-borne virus RNA3-A further example of the heterogeneity of the gene content of furovirus genomes and of triple gene block-carrying RNAs. Virology 216:202-207.

20. Koenig, R., Burgermeister, W., Weich, H., Sebald, W., and Kothe, C. 1986. Uniform RNA patterns of beet necrotic yellow vein virus in sugar beet roots, but not in leaves from several plant species. J. Gen. Virol. 67:20432046.

21. Koenig, R., Jarausch, W., Li, Y., Commandeur, U., Burgermeister, W., Gehrke, M., and Lüddecke, P. 1991. Effect of recombinant beet necrotic yellow vein virus with different RNA compositions on mechanically inoculated sugarbeets. J. Gen. Virol. 72:2243-2246

22. Koenig, R., Lesemann, D. -E., and Burgermeister, W. 1984. Beet necrotic yellow vein virus: purification, preparation of antisera and detection by means of ELISA, immunosorbent electronmicroscopy and electro-blot immunoassay. Phytopathol. Z. 111:244250.

23. Kruse, M., Koenig, R., Hoffman, A., Kaufmann, A., Commandeur, U., Solovyev, A. G., Savenkov, I., and Burgermeister, W. 1994. Restriction fragment length polymorphism analysis of reverse transcription-PCR products reveals the existence of two major strain groups of beet necrotic yellow vein virus. J. Gen. Virol. 75:1835-1842.
24. Laemmli, U. K. 1970. Cleavage of structural proteins during the assembly of the head of bacteriophage T4. Nature 227:680-685.

25. Liu, H. -Y., and Duffus, J. E. 1988. The occurrence of a complex of viruses associated with rhizomania of sugarbeet. Phytopathology 78:1583.

26. Lommel, S. A., Kendall, T. L., Siu, N. F., and Nutter, R. C. 1991. Characterization of maize chlorotic mottle virus. Phytopathology 81:819-823.

27. Putz, C. 1977. Composition and structure of beet necrotic yellow vein virus. J. Gen. Virol. 35:397-401.

28. Putz, C., Pinck, M., Fritsch, C., and Pinck, L 1983. Identification of the 3'- and 5'-ends of beet necrotic yellow vein virus RNAs. FEBS Lett. 156:41-46.

29. Richards, K., Jonard, G., Guilley, H., Ziezler, V., and Putz, C. 1985. In vitro translation of beet necrotic yellow vein virus RNA and studies of sequence homology among the RNA species using cloned cDNA probes. J. Gen. Virol. 66:345-350.

30. Richards, K. E., and Tamada, T. 1992. Mapping functions on the multipartite genome of beet necrotic yellow vein virus. Ann. Rev. Phytopathol. 30:291-313.

31. Rush, C. M., French, R. C., and Heidel, G. B. 1993. Texas 7 a possible strain of beet necrotic yellow vein virus. Pages 59-62 in: Proc. 2nd Symp. Intl. Work. Group Plant Viruses Fungal Vectors. C. Hiruki, ed. American Society of Sugar Beet Technologists, Denver, $\mathrm{CO}$.

32. Rush, C. M., French, R., and Heidel, G. B 1994. Differentiation of two closely related furoviruses using the polymerase chain reaction. Phytopathology 84:1366-1369.

33. Rush, C. M., and Heidel, G. B. 1995. Furovirus diseases of sugar beets in the United States. Plant Dis. 79:868-875.

34. Sambrook, J., Fritsch, E. F., and Maniatas, T. 1989. Molecular Cloning: A Laboratory Manual, 2nd ed. Cold Spring Harbor Laboratory, New York.

35. Schowalter, D. B., and Sommer, S. S. 1989 The generation of radiolabeled DNA and RNA probes with polymerase chain reaction. Anal. Biochem. 177:90-94.

36. Shirako, Y., and Brakke, M. K. 1984. Two purified RNAs of soil-borne wheat mosaic vi rus are needed for infection. J. Gen. Virol. 65:119-127.

37. Shirako, Y., and Brakke, M. K. 1984. Spontaneous deletion mutation of soil-borne wheat mosaic virus RNA II. J. Gen. Virol. 65:855858.

38. Tamada, T. 1975. Beet necrotic yellow vein virus. CMI/AAB Descriptions of Plant Viruses 44. Commonwealth Mycological Institute, Surrey, England.

39. Tamada, T., and Baba, T. 1973. Beet necrotic yellow vein virus from rhizomania-affected sugar beet in Japan. Ann. Phytopathol. Soc. Jpn. 39:325-332.

40. Tamada, T., Shirako, Y., Abe, H., Saito, M., Kiguchi, T., and Harada, T. 1989. Production and pathogenicity of isolates of beet necrotic yellow vein virus with different numbers of RNA components. J. Gen. Virol. 70:33993409 .

41. Torrance, L., and Mayo, M. A. 1997. Proposed re-classification of furoviruses. Arch. Virol. 142:435-439.

42. Towbin, H., Staehelin, T., and Gordon, J. 1979. Electrophoretic transfer of proteins from polyacrylamide gels to nitrocellulose sheets: Procedure and some applications. Proc. Nat. Acad. Sci. U.S.A. 76:4350-4354

43. Wisler, G. C., Duffus, J. E., and Liu, H. -Y 1993. Variations among furoviruses associated with sugarbeet. Pages 63-65 in: Proc 
2nd Symp. Intl. Work. Group Plant Viruses Fungal Vectors. C. Hiruki, ed. American Society of Sugar Beet Technologists, Denver, CO.

44. Wisler, G. C., Liu, H. -Y., and Duffus, J. E. 1994. Beet necrotic yellow vein virus and its relationship to eight sugar beet furo-like viruses from the United States. Plant Dis. 78:995-1001.

45. Wisler, G. C., Widner, J. N., Duffus, J. E., Liu, H. -Y., and Sears, J. L. 1997. A new report of rhizomania and other furoviruses in- fecting sugar beet in Minnesota. Plant Dis. $81: 229$.

46. Xiong, Z., and Lommel, S. A. 1989. The complete nucleotide sequence and genome organization of red clover necrotic mosaic virus RNA-1. Virology 171:543-554. 